\author{
Stanisław PŁONKA ${ }^{1}$ \\ Piotr ZYZAK ${ }^{2}$ \\ Paweł KOBIELA ${ }^{3}$
}

\title{
WPEYW OBCIĄGANIA ŚCIERNICY NA DOKŁADNOŚĆ UZĘBIENIA SZLIFOWANEGO METODĄ KSZTAŁTOWĄ
}

\begin{abstract}
W pracy przedstawiono badania wpływu liczby obciągnięć ściernicy na dokładność szlifowanego uzębienia metodą kształtowo-podziałową. Operacji szlifowania na szlifierce RAPID 2000 firmy Höfler poddano koła zębate wykonane ze stali C55 po frezowaniu obwiedniowym i hartowaniu indukcyjnym, o następującej charakterystyce: $m=5 \mathrm{~mm}, z=68, d_{p}=345,131 \mathrm{~mm}$. Obciąganie ściernicy prowadzono po wyszlifowaniu 9, 13, 17 wrębów koła zębatego. Dla kół zębatych po szlifowaniu ściernicą z różną liczbą obciągnięć wykonano pomiary na współrzędnościowej maszynie pomiarowej następujących odchyłek: odchyłki całkowitej zarysu $F_{\alpha}$, odchyłki kształtu zarysu $f_{f} \alpha$, odchyłki położenia zarysu $f_{H} \alpha$, odchyłki całkowitej linii zęba $F_{\beta}$, odchyłki kształtu linii zęba $f_{f} \beta$, odchyłki położenia linii zęba $f_{H \beta}$, odchyłki podziałki $f_{p}$, odchyłki sumarycznej podziałek koła $F_{p}$, odchyłki bicia promieniowego $F_{r}$.
\end{abstract}

Słowa kluczowe: koła zębate, szlifowanie kształtowo-podziałowe, dokładność uzębienia

\section{Wprowadzenie}

Wysokie wymagania jakościowe stawiane przekładniom zębatym, dotyczące przede wszystkim ich cichobieżności, wymuszają stosowanie obróbki wykończeniowej uzębienia, np. przez szlifowanie, zapewniającej co najmniej 7 klasę dokładności i chropowatość powierzchni $R a \leq 0,8 \mu \mathrm{m}$. Znane są następujące metody szlifowania uzębienia kół zębatych walcowych: kształtowo-podziałowe, obwiedniowo-podziałowe (najczęściej metodą Maaga i metodą Nilesa) oraz obwiedniowe ciągłe (metodą Reishauera) [7-9]. W drugiej połowie XX w.

\footnotetext{
1 Autor do korespondencji/corresponding author: Stanisław Płonka, Akademia Techniczno-Humanistyczna, Bielsko-Biała, ul. Willowa 2, 43-309, tel.: 338279213, e-mail: splonka@ath.bielsko.pl

${ }^{2}$ Piotr Zyzak, Akademia Techniczno-Humanistyczna, Bielsko-Biała, e-mail: pzyzak@ath.bielsko.pl

${ }^{3}$ Paweł Kobiela, Fabryka Reduktorów i Motoreduktorów BEFARED Spółka Akcyjna, Bielsko-Biała, e-mail: pawel.kobiela@befared.pl
} 
w wytwarzaniu kół zębatych walcowych w produkcji przekładni zębatych ogólnego przeznaczenia były na ogół stosowane dwie metody: obwiedniowo-podziałowa oraz obwiedniowa ciągła. Intensywny rozwój układów sterowania numerycznego pod koniec XX i na początku XXI w. spowodował coraz szersze zastosowanie metody kształtowo-podziałowej szlifowania uzębień kół zębatych.

Aby było możliwe szlifowanie boków zębów metodą kształtowo-podziałową, należy nadać określony profil czynnej powierzchni ściernicy. W artykule przedstawiono czynności związane z przygotowaniem szlifierki do obróbki i z obciąganiem ściernicy do szlifowania uzębień walcowych metodą kształtowo-podziałową na szlifierce RAPID 2000 firmy Höfler oraz wybrane wyniki badań własnych dotyczących wpływu obciągania ściernicy na dokładność szlifowanego uzębienia [4-6, 12].

\section{Metodyka i zakres badań}

Badania wpływu liczby obciągnięć ściernicy na dokładność operacji szlifowania kół zębatych walcowych o uzębieniu zewnętrznym przeprowadzono na kołach zębatych o następującej charakterystyce: $m=5 \mathrm{~mm}, z=68, \alpha=20^{\circ}$, $\beta=9^{\circ} 53 ' 30^{\prime \prime}$, współczynnik przesunięcia $x=0 \mathrm{~mm}$ i pochylenie linii zęba prawe. Koła zębate, w liczbie 6 sztuk, wykonano ze stali do ulepszania cieplnego C55 o zawartości następujących pierwiastków stopowych: 0,52-0,60\% C; 0,6-0,9\% Mn; $\max 0,4 \% \mathrm{Si} ; \max 0,045 \% \mathrm{P} ; \max 0,045 \% \mathrm{~S} ; \max 0,4 \% \mathrm{Cr} ; \max$ $0,4 \% \mathrm{Ni}$; $\max 0,1 \%$ Mo. Po operacjach: toczenia zgrubnego, ulepszania cieplnego, toczenia kształtującego, wiercenia i gwintowania drugorzędnych otworów, uzębienie kół zębatych nacinano frezem ślimakowym NM5 PA20 $0^{\circ}$ ze stali szybkotnącej z pokryciem ALCROM A12+ (FUTURA NANO), o następującej charakterystyce: $m=5, \alpha=20^{\circ}, \lambda=2^{\circ} 41^{\prime}$, średnicy frezu $d_{a}=119,8 \mathrm{~mm}$ oraz szerokości frezu $B=140 \mathrm{~mm}$. Operację frezowania uzębienia wykonano na frezarce obwiedniowej SAMPUTENSILI S800 z układem sterowania SINUMERIK. W czasie frezowania obwiedniowego stosowano następujące parametry skrawania: prędkość obrotową freza $n_{f}=186,09 \mathrm{obr} . / \mathrm{min}\left(v_{c}=70 \mathrm{~m} / \mathrm{min}\right)$ i posuw freza $f=2,50 \mathrm{~mm} /$ obr., oraz intensywne chłodzenie i smarowanie olejem obróbkowym MOBILMET 443 zawierającym dodatki uszlachetniające.

Po operacji frezowania oraz gratowania zębów kół zębatych poddano je hartowaniu indukcyjnemu metodą ząb po zębie, do uzyskania twardości 58-60 HRC. Hartowanie indukcyjne poszczególnych zębów odbywało się metodą posuwową, gdzie w trakcie operacji dokonuje się podziału o jeden ząb. Stosowano generator HF $35 \mathrm{~kW}$ oraz podajnik IV-630 przy częstotliwości 300-400 kHz i natężeniu prądu 670 A oraz posuwie maszynowym 2. Grubość warstwy zahartowanej $\sim 1 \mathrm{~mm}$. Po hartowaniu indukcyjnym koła poddano operacji odpuszczania. Opierając się na średnicy wierzchołków zębów (zewnętrznej uzębienia), szlifowano otwór na $\varnothing 100 \mathrm{H} 7$ i powierzchnię prostopadłą do niego (czołową), a następnie 
koło zębate ustawiono na wyszlifowanym otworze oraz powierzchni czołowej, za pomocą tulejki rozprężnej, i szlifowano uzębienie.

W dalszej kolejności należy określić dane dotyczące obciągania ściernicy: liczbę przebiegów obciągania $i_{d}=1$, wartość promieniowego dosuwu obciągacza do ściernicy $a_{d}=0,02 \mathrm{~mm}$ i posuwu obciągacza $f_{d}=0,10 \mathrm{~mm} / \mathrm{obr}$. oraz wskaźnik pokrycia $k_{d}$, będący stosunkiem czynnej szerokości powierzchni obciągacza $b_{d}$ do posuwu obciągacza $f_{d}$. Wskaźnik pokrycia $k_{d}$ wpływa znacząco na chropowatość CPS. Im mniejszy jest wskaźnik pokrycia, tym bardziej chropowata jest czynna powierzchnia ściernicy. Najmniejszy wskaźnik pokrycia $k_{d}=1$. Ustalenie wskaźnika pokrycia zależy od materiału ściernicy. Dla obróbki zgrubnej $2 \leq k_{d} \leq 5$, natomiast dla obróbki wykończeniowej $5 \leq k_{d} \leq 15$ [2]. W operacji obciągania przyjęto parametr $\eta$ oznaczający stosunek prędkości obwodowej rolki obciągającej do prędkości obwodowej ściernicy. Dla ruchu współbieżnego rolki obciągającej i ściernicy należy przyjąć wartości dodatnie tego parametru, natomiast dla ruchu przeciwbieżnego wartości ujemne (rys. 1). W programie szlifowania przyjęto następujące wartości parametrów nastawnych procesu dotyczących obciągania:

- Przejście 1: promieniowe dostawienie obciągacza $a_{d}=0,02 \mathrm{~mm}$, wskaźnik pokrycia $k_{d}=1,0$, parametr obciągania $\eta=0,6$ (prędkość obwodowa rolki obciągającej stanowi 0,6 prędkości obwodowej ściernicy),

- Przejście 2: promieniowe dostawienie obciągacza $a_{d}=0,02 \mathrm{~mm}$, wskaźnik pokrycia $k_{d}=1,0$, parametr obciągania $\eta=0,6$,

- Przejście 3: promieniowe dostawienie obciągacza $a_{d}=0,02 \mathrm{~mm}$, wskaźnik pokrycia $k_{d}=1,5$, parametr obciągania $\eta=-0,3$,

- Przejście 4: promieniowe dostawienie obciągacza $a_{d}=0,02 \mathrm{~mm}$, wskaźnik pokrycia $k_{d}=6,0$, parametr obciągania $\eta=-0,6$.

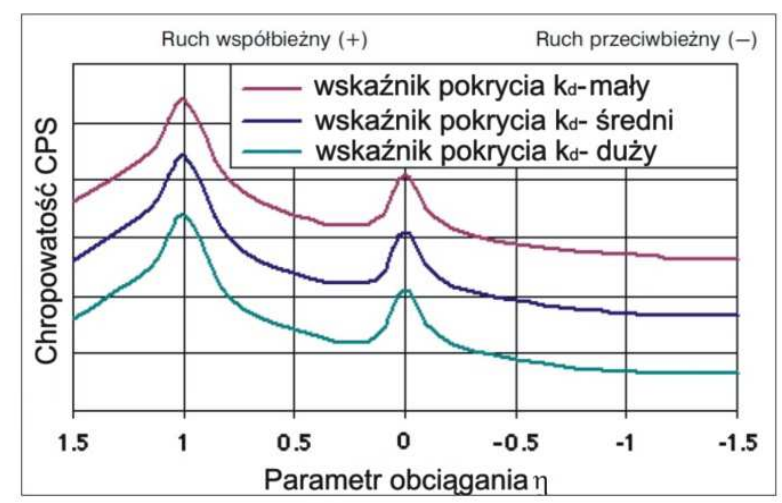

Rys. 1. Zależność chropowatości CPS od wskaźnika pokrycia $k_{d}$ oraz parametru obciągania $\eta$

Fig. 1. CPS surface roughness in a function of $k_{d}$ teeth overlaps index and $\eta$ truing parameter 
Na szlifierkach sterowanych numerycznie typu Rapid 2000 firmy Höfler do obciągania konwencjonalnych ściernic płaskich i profilowych wykorzystuje się rolki obciągające z nasypem diamentowym. Sterowanie numeryczne umożliwia sterowanie kątem pochylenia rolki, co w połączeniu z przemieszczeniem ściernicy pozwala na kształtowanie dowolnego profilu ściernicy. Podczas realizacji badań doświadczalnych do obciągania ściernicy wykorzystano rolki obciągające NC 32730/6. W następnym kroku należy dokonać ustawienia (wypośrodkowania) ściernicy, które obejmuje: znalezienie wrębu (zgrubne ustalenie pozycji wrębu), oraz centrowanie wrębu (dokładne ustalanie środka wrębu). Znalezienie wrębu przeprowadzono ręcznie, wprowadzając ściernicę we wrąb na głębokość średnicy podziałowej $d_{p}$ koła zębatego. Centrowanie wrębu zostało zrealizowane automatycznie przez zetknięcie ściernicy z lewym i prawym bokiem wrębu, co pozwoliło na określenie podziału naddatku. Centrowanie wykonano w dwóch płaszczyznach: górnej oraz dolnej, które są symetrycznie rozłożone na szerokości wieńca zębatego dla sześciu wrębów równomiernie rozłożonych na obwodzie koła. Po hartowaniu indukcyjnym oraz odpuszczaniu realizowano operację szlifowania zębów kół zębatych, a następnie dokonano kontroli uzębień, mycia i konserwowania.

Do szlifowania kół zębatych użyto jednoprofilowej ściernicy z elektrokorundu T1ESP-400×45×27-V60-U12-93A80/80F15VPH601W firmy 3M, zaprofilowanej na moduł $m=5 \mathrm{~mm}$, profil E (50 Grad). Warunki operacji szlifowania: prędkość obwodowa szlifowania $v_{s}=30 \mathrm{~m} / \mathrm{s}$ dla ściernicy $400 \mathrm{~mm}$, prędkość ruchu posuwisto-zwrotnego ściernicy dla: przejść zgrubnych $v_{f}=7 \mathrm{~m} / \mathrm{min}$, przejść kształtujących $v_{f}=4,5 \mathrm{~m} / \mathrm{min}$, przejść wykończeniowych $v_{f}=2,2 \mathrm{~m} / \mathrm{min}$, naddatek całkowity na szlifowanie $C_{c}=0,31 \mathrm{~mm}$, naddatek dla przejść zgrubnych $C_{z}=0,24 \mathrm{~mm}$ (głębokość szlifowania dla przejść zgrubnych $a_{p(z)}=0,02 \mathrm{~mm}$ ), naddatek dla przejść kształtujących $C_{k}=0,05 \mathrm{~mm}$ (głębokość szlifowania dla przejść kształtujących $a_{p(k)}=0,015 \mathrm{~mm}, i_{p}=2$ przejścia i $a_{p(k)}=0,01 \mathrm{~mm}, i_{p}=2$ przejścia), naddatek na szlifowanie wykończeniowe $C_{w}=0,02 \mathrm{~mm}$ (głębokość szlifowania dla przejść wykończeniowych $\left.a_{p(w)}=0,01 \mathrm{~mm}, i_{p}=2\right)$, płyn obróbkowy: olej Rotel Spezial 277-4 o wydatku 220 1/min.

\section{Wyniki pomiarów i ich analiza}

Po zakończeniu realizacji operacji frezowania uzębienia oznaczono koła numerami od 1 do 3. Wykonano również cechy na każdym oznakowanym kole, oznaczające pierwszy jego wrąb. Szlifowanie każdego koła zębatego rozpoczynano od wrębu oznaczonego numerem 1 . Przed rozpoczęciem szlifowania wrębu 1 ściernica była obciągana. Układ sterowania numerycznego szlifierki umożliwia wybór dwóch strategii obciągania. Do wyboru są dwie metody: liczba wrębów (ściernica obciągana jest po szlifowaniu podanej liczby wrębów), określona objętość skrawania (obciąganie następuje po osiągnięciu zdefiniowanej wartości objętości warstwy usuniętej). W badaniach własnych zastosowano metodę obcią- 
gania polegającą na ustaleniu liczby wrębów. Tabela 1 zawiera informacje o wariantach obciągania ściernicy do szlifowania kół zębatych (w nawiasach podana liczba oznacza numer wrębu, który jest szlifowany jako ostatni przed obciąganiem ściernicy).

Tabela 1. Warianty obciągania ściernicy do szlifowania badanych kół zębatych Table 1. Truing variants of the grinding wheel for grinding of the tested gear wheels

\begin{tabular}{|c|c|c|c|c|c|}
\hline Nr koła & \multicolumn{5}{|c|}{ Wrąb (numer) } \\
\hline \multirow[t]{3}{*}{1} & \multicolumn{5}{|c|}{$\begin{array}{l}\text { [co } 9 \text { wrąb - obciąganie] dla każdego przejścia. } \\
\text { Liczba obciągnięć ściernicy }-7\end{array}$} \\
\hline & 1 & $10(9)$ & 19(18) & $28(27)$ & $37(36)$ \\
\hline & & $46(45)$ & $55(54)$ & $64(63)$ & \\
\hline \multirow[t]{3}{*}{2} & \multicolumn{5}{|c|}{$\begin{array}{l}\text { [co } 13 \text { wrąb - obciąganie] dla każdego przejścia. } \\
\text { Liczba obciągnięć ściernicy - } 5\end{array}$} \\
\hline & 1 & $14(13)$ & $27(26)$ & $40(39)$ & $53(52)$ \\
\hline & & $66(65)$ & & & \\
\hline \multirow[t]{2}{*}{3} & \multicolumn{5}{|c|}{$\begin{array}{l}\text { [co } 17 \text { wrąb - obciąganie] dla każdego przejścia. } \\
\text { Liczba obciągnięć ściernicy - } 4\end{array}$} \\
\hline & 1 & $18(17)$ & $35(34)$ & $52(51)$ & $68(67)$ \\
\hline
\end{tabular}

Pomiary dokładności uzębienia badanych kół zębatych przeprowadzono oddzielnie po operacjach frezowania, hartowania indukcyjnego oraz szlifowania na maszynie współrzędnościowej typu ZEISS PRISMO NAVIGATOR firmy CARL ZEISS skaningową głowicą pomiarową Vast Gold, wykorzystując oprogramowanie ZEISS GEAR PRO involute 2014. Maksymalny błąd dopuszczalny współrzędnościowej maszyny pomiarowej MPE $=2+3 L[\mu \mathrm{m}]$, gdzie: $L-$ wartość liczbowa mierzonej długości $\mathrm{w} \mathrm{m}$. $\mathrm{W}$ każdym kole zmierzono lewą i prawą stronę wrębów szlifowanych ściernicą przed obciąganiem i bezpośrednio po obciąganiu dla oznaczonego koła zębatego (tab. 1). W pracy do oceny dokładności wykonania uzębienia przyjęto wg PN-ISO 1328-1:2013(E): całkowitą odchyłkę zarysu $F_{\alpha}$, odchyłkę położenia zarysu $f_{H \alpha}$, odchyłkę kształtu zarysu $f_{f \alpha}$, całkowitą odchyłkę linii zęba $F_{\beta}$, odchyłkę położenia linii zęba $f_{H \beta}$, odchyłkę kształtu linii zęba $f_{f \beta}$, odchyłkę sumaryczną podziałek koła $F_{p}$, odchyłkę podziałki $f_{p}$ oraz bicie promieniowe $F_{r}[1,3,10,11]$.

Ze względu na to, że uzębienie koła miało być wykonane w 6 klasie dokładności, a norma ISO 1328-1:2013 (E) zaleca do oceny kół zębatych o średnicy $d \leq 4000 \mathrm{~mm}$ w klasie od 1 do 6 następujące parametry: $F_{p}, f_{p}, s, F_{\alpha}, f_{H \alpha}, f_{f \alpha}, F_{\beta}$, $f_{H \beta}, f_{f \beta}$, ograniczono się do analizy tylko tych wielkości (z wyjątkiem parametru $s$ ). Dodatkowo, w ocenie dokładności uzębienia kół zębatych uwzględniono bicie promieniowe $F_{r}$. Średnie wartości odchyłek: $F_{\alpha}, f_{H \alpha}, f_{f \alpha}, F_{\beta}, f_{H \beta}, f_{f \beta}, f_{p}, F_{p}, F_{r}$ uzyskanych z pomiarów dla lewej i prawej strony wrębu, przyjętych do oceny 
dokładności szlifowanego uzębienia zamieszczono w tab. 2-4. Wartości zmierzonych odchyłek: $F_{\alpha}, f_{H \alpha}, f_{f \alpha}, F_{\beta}, f_{H \beta}, f_{f \beta}, f_{p}, F_{p}, F_{r}$ szlifowanego uzębienia dla pierwszego wrębu po obciąganiu ściernicy i po wyszlifowaniu 9, 13 oraz 17 wrębów przedstawiono na rys. 2 .

Po operacji frezowania obwiedniowego frezem ślimakowym klasy Bp średnie wartości całkowitej odchyłki zarysu $F_{\alpha}$ mieściły się, dla lewej strony wrębu, w przedziale 12,9-13,8 $\mu \mathrm{m}$ (co odpowiada 6 klasie dokładności), odchyłki kształtu zarysu $f_{f a}$ w przedziale 12,9-13,2 $\mu \mathrm{m}$ (7 klasa), odchyłki położenia zarysu $f_{H \alpha}$ w przedziale $-0,6--3,6 \mu \mathrm{m}$ ( 3 klasa), całkowite odchyłki linii zęba $F_{\beta}$ w przedziale 9,9-17,8 $\mu \mathrm{m}$ (6 klasa), odchyłki kształtu linii zęba $f_{f \beta}$ w przedziale 9,4-13,2 $\mu \mathrm{m}$ (7 klasa), odchyłki położenia linii zęba $f_{H \beta} \mathrm{w}$ przedziale $-1,0--15,5 \mu \mathrm{m}$ (7 klasa). Z kolei średnie wartości całkowitej odchyłki zarysu $F_{\alpha}$ dla prawej strony wrębu są większe: od 32,7 do 90,7\% (co odpowiada 8 klasie dokładności), odchyłki kształtu zarysu $f_{f \alpha}$ są większe od 34,8 do $50 \%$ (8 klasa), a odchyłki położenia zarysu $f_{H \alpha}$ są mniejsze (wartości tych odchyłek mieszczą się w 1 klasie dokładności). Średnie wartości całkowitej odchyłki linii zęba $F_{\beta}$ dla prawej strony wrębu są na ogół większe: od 27,0 do 45,2\% (co odpowiada 7 klasie dokładności), odchyłki kształtu linii zęba $f_{f \beta}$ są prawie identyczne z uzyskanymi w przypadku lewej strony wrębu, a odchyłki położenia linii zęba $f_{H \beta}$ są znacząco większe: od 106,5 do 190,6\%, od średnich wartości tych odchyłek dla lewej strony wrębu. Maksymalna wartość odchyłki $f_{f \beta}$ po frezowaniu wyniosła $26 \mu \mathrm{m}$, co daje 8 klasę dokładności koła zębatego. Wartości odchyłki podziałki $f_{p}$ po frezowaniu obwiedniowym zawierają się w przedziale 3,0-3,5 $\mu \mathrm{m}$ (3 klasa), odchyłki sumarycznej podziałek $F_{p}$ w przedziale $6,5-21,0 \mu \mathrm{m}$ (4 klasa), a bicia promieniowego $F_{r}$ w przedziale 7,0-24,0 $\mu \mathrm{m}$ (6 klasa). W wyniku operacji hartowania indukcyjnego następuje nieznaczny wzrost wartości odchyłek $F_{\alpha}, f_{H \alpha}, f_{f \alpha}$ oraz znaczący wzrost odchyłek $F_{\beta}, f_{H \beta}, f_{f \beta}, f_{p}, F_{p}, F_{r}$. Maksymalna wartość odchyłki $F_{\beta}$ po hartowaniu indukcyjnym wyniosła $30 \mu \mathrm{m}$, co daje 8 klasę dokładności koła zębatego, a odchyłki $f_{f \beta} 35 \mu \mathrm{m}$, co daje 9 klasę dokładności koła zębatego.

Zastosowanie operacji szlifowania uzębienia metodą kształtowo-podziałową spowodowało bardzo znaczące zmniejszenie wartości prawie wszystkich badanych odchyłek. Przykładowo średnie wartości całkowitej odchyłki zarysu $F_{\alpha}$ uległy po operacji szlifowania zmniejszeniu od 5,2 do 9,2 razy, a całkowitej odchyłki linii zęba $F_{\beta}$ od 5,0 do 11,5 razy. Maksymalna wartość całkowitej odchyłki zarysu $F_{\alpha}$ po szlifowaniu wyniosła $3,0 \mu \mathrm{m}$, odchyłki kształtu zarysu $f_{f \alpha}$ $3,0 \mu \mathrm{m}$, odchyłki położenia zarysu $f_{H \alpha} 1 \mu \mathrm{m}$ (co odpowiada 2 klasie dokładności), natomiast całkowita odchyłka linii zęba $F_{\beta}=4,0 \mu \mathrm{m}$, odchyłka kształtu linii zęba $f_{f \beta}=2 \mu \mathrm{m}$, odchyłka położenia linii zęba $f_{H \beta}=3$ (2 klasa). Maksymalna wartość odchyłki podziałki $f_{p}$ wyniosła $3,0 \mu \mathrm{m}$ (3 klasa), odchyłki sumarycznej podziałek koła $F_{p}=7,0 \mu \mathrm{m}$ ( 1 klasa) oraz bicia promieniowego $F_{r}=11,0 \mu \mathrm{m}$ (4 klasa). 
Tabela 2. Średnie wartości odchyłek dokładności wykonania uzębienia po frezowaniu, hartowaniu indukcyjnym oraz szlifowaniu z określonym wariantem obciągania ściernicy co 9 wrąb

Table 2. Average values of deviations of fabrication accuracy of the teeth after milling, induction hardening and grinding with determined truing variant of the grinding wheel at every $9^{\text {th }}$ tooth space

\begin{tabular}{|c|c|c|c|c|c|c|c|c|c|c|c|c|c|c|c|}
\hline & \multicolumn{12}{|c|}{ Wartości średnie odchyłek dla wariantu obciągania co 9 wrąb $[\mu \mathrm{m}]$} & \multirow{2}{*}{\multicolumn{3}{|c|}{$\begin{array}{l}\text { Wartości odchy- } \\
\text { łek z pomiarów } \\
\text { dla wariantu } \\
\text { obciągania co } \\
9 \text { wrąb }[\mu \mathrm{m}] \\
\end{array}$}} \\
\hline & \multicolumn{6}{|c|}{$\begin{array}{l}\text { lewa strona wrębu szlifowanego } \\
\text { po obciąganiu ściernicy }\end{array}$} & \multicolumn{6}{|c|}{$\begin{array}{l}\text { prawa strona wrębu szlifowanego } \\
\text { po obciąganiu ściernicy }\end{array}$} & & & \\
\hline & $F_{\alpha}$ & $f_{f \alpha}$ & $f_{H \alpha}$ & $F_{\beta}$ & $f_{f \beta}$ & $f_{H \beta}$ & $F_{\alpha}$ & $f_{f \alpha}$ & $f_{H \alpha}$ & $F_{\beta}$ & $f_{f \beta}$ & $f_{H \beta}$ & $f_{p}$ & $F_{p}$ & $F_{r}$ \\
\hline Frezowanie & 12,9 & 12,9 & $-2,3$ & 10,0 & 9,4 & $-1,6$ & 20,3 & 19,8 & $-0,9$ & 17,6 & 9,5 & 15,3 & 3,0 & 6,5 & 7,0 \\
\hline $\begin{array}{l}\text { Hartowanie } \\
\text { indukcyjne }\end{array}$ & 3,0 & 13,0 & 1,4 & 17,4 & 12,4 & $-15,6$ & 23,9 & 21,0 & 4,8 & 19,5 & 12,1 & 17,5 & 4,0 & 23,5 & 31,0 \\
\hline \multirow[t]{3}{*}{ Szlifowanie } & 2,5 & 1,0 & $-2,4$ & 2,0 & 2,0 & 0,6 & 1,9 & 2,0 & 0,1 & 1,8 & 1,5 & $-0,6$ & 3,0 & 7,0 & 7,0 \\
\hline & \multicolumn{6}{|c|}{$\begin{array}{c}\text { lewa strona wrębu po szlifowaniu } \\
9 \text { wrębów }\end{array}$} & \multicolumn{6}{|c|}{$\begin{array}{c}\text { prawa strona wrębu po szlifowaniu } \\
9 \text { wrębów }\end{array}$} & & & \\
\hline & $F_{\alpha}$ & $f_{f \alpha}$ & $f_{H_{\alpha}}$ & $F_{\beta}$ & $f_{f \beta}$ & $f_{H \beta}$ & $F_{\alpha}$ & $f_{f \alpha}$ & $f_{H \alpha}$ & $F_{\beta}$ & $f_{f \beta}$ & $f_{H \beta}$ & & & \\
\hline Frezowanie & 13,6 & 13,0 & $-2,1$ & 9,9 & \begin{tabular}{|l|l|}
9,6 \\
\end{tabular} & $-1,0$ & 20,4 & 20,0 & $-1,4$ & 18,0 & \begin{tabular}{|l|}
9,1 \\
\end{tabular} & 15,3 & & & \\
\hline $\begin{array}{l}\text { Hartowanie } \\
\text { indukcyjne }\end{array}$ & 13,7 & 13,7 & 1,4 & 17,3 & 12,7 & $-14,9$ & 23,6 & 21,1 & 4,7 & 19,6 & 11,3 & 18,3 & & & \\
\hline Szlifowanie & 2,4 & 1,0 & $-2,3$ & 1,7 & 2,0 & 0,7 & 2,0 & 1,9 & 0,6 & 1,6 & 1,1 & $-0,3$ & & & \\
\hline
\end{tabular}

Tabela 3. Średnie wartości odchyłek dokładności wykonania uzębienia po frezowaniu, hartowaniu indukcyjnym oraz szlifowaniu z określonym wariantem obciągania ściernicy co 13 wrąb

Table 3. Average values of deviations of fabrication accuracy of the teeth after milling, induction hardening and grinding with determined truing variant of the grinding wheel at every $13^{\text {th }}$ tooth space

\begin{tabular}{|c|c|c|c|c|c|c|c|c|c|c|c|c|c|c|c|}
\hline & \multirow{2}{*}{\multicolumn{12}{|c|}{ Wartości średnie odchyłek dla wariantu obciągania co 13 wrąb [ $\mu \mathrm{m}]$}} & \multirow{3}{*}{\multicolumn{3}{|c|}{$\begin{array}{c}\text { Wartości odchy } \\
\text { łek z pomiarów } \\
\text { dla wariantu } \\
\text { obciągania co } \\
13 \text { wrąb }[\mu \mathrm{m}]\end{array}$}} \\
\hline & & & & & & & & & & & & & & & \\
\hline & \multicolumn{6}{|c|}{$\begin{array}{c}\text { lewa strona wrębu szlifowanego } \\
\text { po obciąganiu ściernicy }\end{array}$} & \multicolumn{6}{|c|}{$\begin{array}{c}\text { prawa strona wrębu szlifowanego po } \\
\text { obciąganiu ściernicy }\end{array}$} & & & \\
\hline & $F_{\alpha}$ & $f_{f \alpha}$ & $f_{H \alpha}$ & $F_{\beta}$ & $f_{f \beta}$ & $f_{H \beta}$ & $F_{\alpha}$ & $f_{f \alpha}$ & $f_{H \alpha}$ & $F_{\beta}$ & $f_{f \beta}$ & $f_{H \beta}$ & $f_{p}$ & $F_{p}$ & $F_{r}$ \\
\hline Frezowanie & 13,2 & 12,3 & \begin{tabular}{|l|}
$-0,7$ \\
\end{tabular} & 12,2 & 10,0 & $-6,3$ & 23,0 & 22,8 & $-1,3$ & 16,7 & 10,2 & 16,8 & 3,0 & 21,0 & 11,0 \\
\hline $\begin{array}{l}\text { Hartowanie } \\
\text { indukcyjne }\end{array}$ & 13,8 & 12,8 & $-4,7$ & 17,0 & 12,3 & $-16,2$ & 24,8 & 23,3 & 2,7 & 21,5 & 13,5 & 16,8 & 4,0 & 23,0 & 14,0 \\
\hline \multirow[t]{3}{*}{ Szlifowanie } & 2,0 & 1,3 & $-1,0$ & 1,7 & 1,0 & $-0,2$ & 1,7 & 1,3 & 0,3 & 2,2 & 1,0 & $-0,7$ & 2,0 & 5,5 & 11,0 \\
\hline & \multicolumn{6}{|c|}{$\begin{array}{c}\text { lewa strona wrębu po szlifowaniu } \\
13 \text { wrębów }\end{array}$} & \multicolumn{6}{|c|}{$\begin{array}{c}\text { prawa strona wrębu po szlifowaniu } \\
13 \text { wrębów }\end{array}$} & & & \\
\hline & $F_{\alpha}$ & $f_{f \alpha}$ & $f_{H \alpha}$ & $F_{\beta}$ & $f_{f \beta}$ & $f_{H \beta}$ & $F_{\alpha}$ & $f_{f \alpha}$ & $f_{H \alpha}$ & $F_{\beta}$ & $f_{f \beta}$ & $f_{H \beta}$ & & & \\
\hline Frezowanie & 13,6 & 13,0 & $-0,6$ & 12,0 & \begin{tabular}{|l|}
9,6 \\
\end{tabular} & $-6,4$ & 26,0 & 26,0 & 0,0 & 19,0 & 12,4 & 16,8 & & & \\
\hline $\begin{array}{l}\text { Hartowanie } \\
\text { indukcyjne }\end{array}$ & 14,4 & 13,4 & $-4,2$ & 16,8 & 12,2 & $-15,8$ & 24,2 & 22,8 & 3,0 & 21,0 & 13,0 & 20,0 & & & \\
\hline \begin{tabular}{|l|} 
Szlifowanie \\
\end{tabular} & 1,6 & 1,2 & \begin{tabular}{|l|}
$-0,8$ \\
\end{tabular} & 2,0 & 1,0 & $-0,2$ & 1,4 & 1,0 & 0,4 & 2,0 & 1,0 & $-1,0$ & & & \\
\hline
\end{tabular}


Tabela 4. Średnie wartości odchyłek dokładności wykonania uzębienia po frezowaniu, hartowaniu indukcyjnym oraz szlifowaniu z określonym wariantem obciągania ściernicy co 17 wrąb

Table 4. Average values of deviations of fabrication accuracy of the teeth after milling, induction hardening and grinding with determined truing variant of the grinding wheel at every $17^{\text {th }}$ tooth space

\begin{tabular}{|c|c|c|c|c|c|c|c|c|c|c|c|c|c|c|c|}
\hline & \multirow{2}{*}{\multicolumn{12}{|c|}{ Wartości średnie odchyłek dla wariantu obciągania co 17 wrąb $[\mu \mathrm{m}]$}} & \multirow{3}{*}{\multicolumn{3}{|c|}{\begin{tabular}{|c|} 
Wartości od- \\
chyłek z po- \\
miarów dla \\
wariantu ob- \\
ciągania co \\
17 wrąb $[\mu \mathrm{m}]$
\end{tabular}}} \\
\hline & & & & & & & & & & & & & & & \\
\hline & \multicolumn{6}{|c|}{$\begin{array}{l}\text { lewa strona wrębu szlifowanego } \\
\text { po obciąganiu ściernicy }\end{array}$} & \multicolumn{6}{|c|}{$\begin{array}{l}\text { prawa strona wrębu szlifowanego } \\
\text { po obciąganiu ściernicy }\end{array}$} & & & \\
\hline & $F_{\alpha}$ & $f_{f \alpha}$ & $f_{H \alpha}$ & $F_{\beta}$ & $f_{f \beta}$ & $f_{H \beta}$ & $F_{\alpha}$ & $f_{f \alpha}$ & $f_{H \alpha}$ & $F_{\beta}$ & $f_{f \beta}$ & $f_{H \beta}$ & $f_{p}$ & $F_{p}$ & $F_{r}$ \\
\hline Frezowanie & 13,8 & 13 & $-3,6$ & 17,8 & 12,6 & $-15,4$ & 21,2 & 21,2 & $-1,4$ & 18 & 11,8 & 17 & 3,5 & 21,0 & 24,0 \\
\hline $\begin{array}{l}\text { Hartowanie } \\
\text { indukcyjne }\end{array}$ & 14 & 14,4 & 0,8 & 20,2 & 18,4 & $-16,8$ & 22,8 & 22,4 & 2,4 & 25,8 & 12,8 & 28,8 & 4,0 & 23,0 & 26,0 \\
\hline \multirow[t]{3}{*}{ Szlifowanie } & 2 & 1 & $-1,6$ & 1,8 & \begin{tabular}{|l|}
1 \\
\end{tabular} & 0,2 & \begin{tabular}{|l|}
1,2 \\
\end{tabular} & 1,4 & $-0,6$ & 2,2 & 1 & $-0,2$ & 2,0 & 6,0 & 11,0 \\
\hline & \multicolumn{6}{|c|}{\begin{tabular}{|c|} 
lewa strona wrębu po szlifowaniu 17 \\
wrębów
\end{tabular}} & \multicolumn{6}{|c|}{\begin{tabular}{|c|} 
prawa strona wrębu po szlifowaniu \\
17 wrębów \\
\end{tabular}} & & & \\
\hline & $F_{\alpha}$ & $f_{f \alpha}$ & $f_{H \alpha}$ & $F_{\beta}$ & $f_{f \beta}$ & $f_{H \beta}$ & $F_{\alpha}$ & $f_{f \alpha}$ & $f_{H \alpha}$ & $F_{\beta}$ & \begin{tabular}{|l|}
$f_{f \beta}$ \\
\end{tabular} & $f_{H \beta}$ & & & \\
\hline Frezowanie & 13,8 & 13,3 & $-2,8$ & 17,8 & 13,3 & $-15,5$ & 21,0 & 21,0 & $-1,3$ & 16,5 & 10,3 & 16,3 & & & \\
\hline $\begin{array}{l}\text { Hartowanie } \\
\text { indukcyjne }\end{array}$ & 14,3 & 13,5 & 1,0 & 20,0 & 17,3 & $-16,8$ & 22,5 & 21,3 & 2,5 & 26,3 & 12,3 & 27,8 & & & \\
\hline Szlifowanie & 1,5 & 1,0 & $-1,3$ & 1,5 & 1,0 & 0,8 & 1,5 & 1,8 & $\mid-0,5$ & 2,0 & 1,0 & 0,3 & & & \\
\hline
\end{tabular}

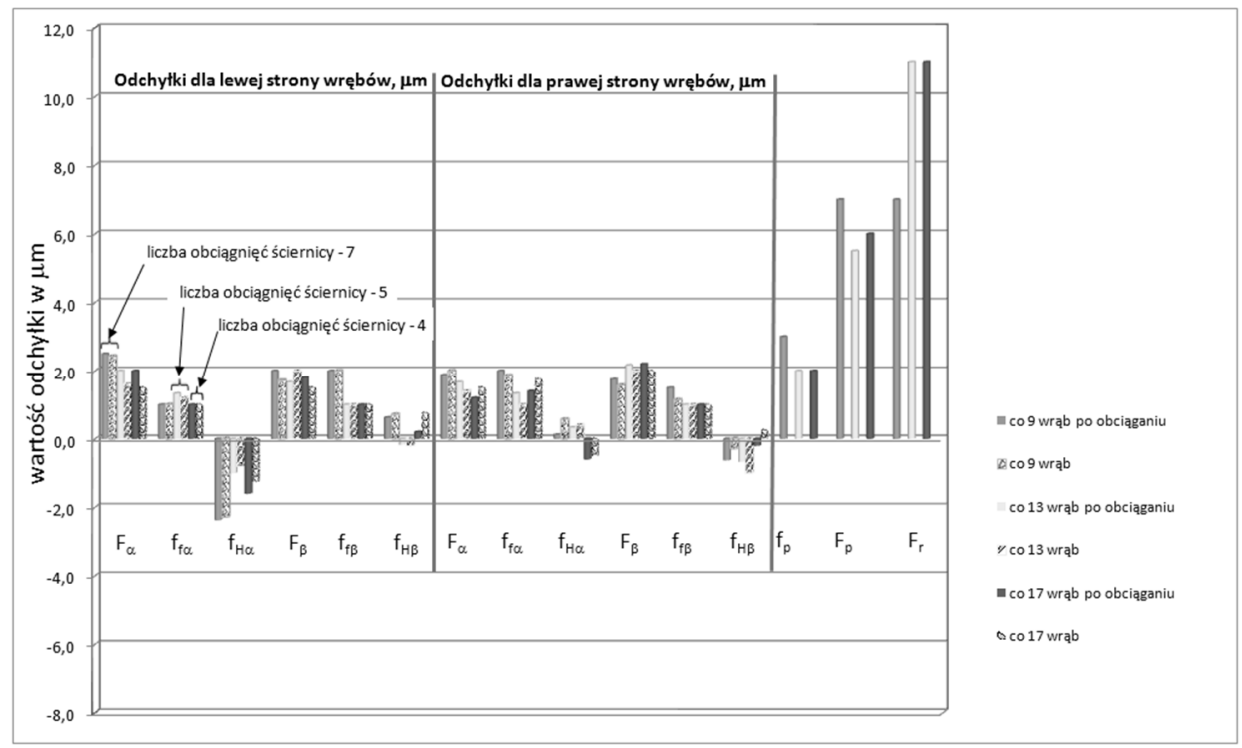

Rys. 2. Średnie wartości odchyłek dokładności wykonania uzębienia po szlifowaniu z określoną liczbą obciągnięć ściernicy

Fig. 2. Average values of deviations of fabrication accuracy of the teeth after grinding with the specified number of truing the grinding wheel 
Przykładowo, odchylenie standardowe wyników pomiarów całkowitej odchyłki zarysu $F_{\alpha}$ dla kół zębatych szlifowanych ściernicą obciąganą co 9 wrąb dla lewej strony zęba wynosi $s_{(l)}=0,53 \mu \mathrm{m}$, a dla prawej $s_{(p)}=0,35 \mu \mathrm{m}$. $\mathrm{Z}$ kolei dla kół zębatych szlifowanych ściernicą obciąganą co 13 wrąb odchylenie standardowe dla lewej strony zęba wynosi $s_{(l)}=0,54 \mu \mathrm{m}$, a dla prawej $s_{(p)}=0,81 \mu \mathrm{m}$. W przypadku kół zębatych szlifowanych ściernicą obciąganą co 17 wrąb odchylenie standardowe zarówno dla lewej, jak i prawej strony wynosi $s_{(l)}=s_{(p)}=0,57 \mu \mathrm{m}$.

Nie stwierdzono w badanym zakresie wpływu liczby obciągnięć ściernicy na obwodzie koła na dokładność uzębienia kół zębatych. Należy to tłumaczyć dużą trwałością ściernicy oraz obciąganiem ściernicy po przeszlifowaniu stosunkowo niewielkiej liczby wrębów (rys. 2).

\section{Podsumowanie}

Przeprowadzone badania częstości obciągania ściernicy nie wykazały jej wpływu na dokładność szlifowania uzębień metodą kształtowo-podziałową. Należy to tłumaczyć przede wszystkim zbyt częstym obciąganiem ściernicy po przeszlifowaniu stosunkowo niewielkiej liczby wrębów. Po operacji frezowania frezem ślimakowym klasy Bp dokładność uzębienia kół zębatych mieściła się w klasie 8, natomiast po operacji hartowania indukcyjnego nastąpiło pogorszenie dokładności uzębienia o 1 klasę ( 9 klasa dokładności). Zastosowanie operacji szlifowania metodą kształtowo-podziałową po frezowaniu i następnie hartowaniu indukcyjnym spowodowało zmniejszenie badanych odchyłek od kilku do kilkunastu razy i umożliwiło wykonanie uzębienia kół zębatych w 4 klasie dokładności.

\section{Literatura}

[1] DIN 3962 (1978): Toleranze für Stirnradverzahnungen. Toleranze für abweichungen einzelner Bestimmungsgrößen.

[2] Instrukcja obsługi szlifierki kształtowo-podziałowej Rapid 2000 do obróbki wykończeniowej uzębień firmy Höfler (Niemcy).

[3] ISO 1328-1: 2013 (E): Cylindrical gears - ISO system of flank tolerance classification. Part 1: Definitions and allowable values of deviations relevant to flanks of gear teeth.

[4] Koziarski A.: Czynna powierzchnia ściernicy. Metody badań makro- i mikrogeometrii, Monografie, Politechnika Łódzka 1996.

[5] Krzempek A., Płonka S., Tubielewicz K.: Metody obciągania ściernicy ślimakowej oraz ich wpływ na dokładność szlifowanego uzębienia. Monografia 99. Budowa i Eksploatacja Maszyn, Wydawn. Politechniki Częstochowskiej, Częstochowa.

[6] Mazurowicz R., Raczyk R.: Przyrządy do profilowania ściernic ślimakowych do szlifowania kół zębatych metodą Reishauer, Mechanik, 71 (1998) 599-600.

[7] Ochęduszko K.: Koła zębate. T. II. Wykonanie i montaż, WNT, Warszawa 1992. 
[8] Oczoś K., Marciniec J.: Rozwój konstrukcji obrabiarek do realizacji procesów szlifowania. Cz. II, Mechanik, 79 (2006) 192-198.

[9] Oczoś K., Porzycki J.: Szlifowanie. Podstawy i technika, WNT, Warszawa 1986.

[10] PN-ISO 1328-1 (1997): Przekładnie zębate walcowe. Dokładność wykonania według ISO. Definicje i wartości odchyłek jednoimiennych boków zębów.

[11] PN-ISO 1328-2 (1997): Definicje i wartości odchyłek pomiarowych złożonych i odchyłek bicia.

[12] Rybak J.: Badania dokładności kształtowania ściernic ślimakowych oraz niektóre aspekty jej wpływu na dokładność szlifowania uzębień, Praca doktorska, Politechnika Poznańska, Poznań 1971.

\section{EFFECT OF TRUING OF GRINDING WHEEL ON ACCURACY OF GEAR TEETH GRINDED WITH THE USE OF PROFILE METHOD}

\section{S u m m a r y}

In this paper the results of investigations concerning the effects of number of truing operations of a grinding wheel on accuracy of gear wheel grinded with the use of profile dividing method are presented. The grinding operation was performed on the gear wheels made of hobbed and induction hardened C55 steel on grinding machine of RAPID 2000 made by Höfler Company. The gear wheels parameters were as follows: $m=5 \mathrm{~mm}, z=68, d_{p}=345,131 \mathrm{~mm}$. Truing of the grinding wheel was performed after grinding of $9,13,17$ tooth spaces of the gear wheel. The measurements of deviations of gear wheels were conducted on coordinate measuring machine. Following deviations are measured: total profile deviation $F_{\alpha}$, profile form deviation $f_{f \alpha}$, profile slope deviation $f_{H \alpha}$, total helix deviation $F_{\beta}$, helix form deviation $f_{f \beta}$, helix slope deviation $f_{H \beta}$, single pitch deviation $f_{p}$, total cumulative pitch deviation $F_{p}$, radial runout deviation $F_{r}$.

Keywords: gear wheels, profile dividing grinding, accuracy of toothing

DOI: $10.7862 / \mathrm{rm} .2017 .50$

Przestano do redakcji: 22.08 .2017

Przyjęto do druku: 18.10.2017 